\title{
Importance of Plants as depicted in Purānas
}

\author{
Dhananjay Vasudeo Dwivedi*
}

(Received 03 November 2016; revised 07 July 2017)

\begin{abstract}
Plants according to the Purānas ${ }^{1}$ give happiness both here alone on the earth and hereafter. The paper highlights the importance of plants from religious, cultural, ritualistic and economic point of view. Viṣnudharmottara Purāna describes that by offering flowers to God, one gets blessings and leads propitious, prosperous and auspicious life. Offering flowers to deities also results in better fortune, glory, supremacy, opulence and happiness of mind. The plants described in Purānas include Āmalakī, Aśoka, Bilva, Khadira, Tulasī, Aśvattha etc. Economically the plants play a vital role in making of garment, cosmetics, ornament and wood based industries etc. Plants are richest source of food and also have medicinal use.
\end{abstract}

Key words: Cultural, Economic, Medicinal, Plants, Purāna, Religious

\section{INTRODUCTION}

Plants are significant part of nature. They have been described in Sanskrit Literature as part and parcel of human civilization and have played vital role in almost all the spheres of human life. According to the Indian Tradition, not only plants are an important ingredient of nature, but the existence of the world sans plant kingdom is also impossible. Life cannot run smoothly without them. From time immemorial, plants provide food, cloths, medicines, dwellings and many other things indispensable for survival and prosperity. It goes without saying that among various constituents of nature, high importance has been given to the plants, since, plants have profoundly influenced the culture and civilisation of man from pre-historic times. By going through the Sanskrit Literature, it is crystal clear that the extent to which plants in India is used in worship and medicine is unrivalled and unparalleled. There is hardly any sphere of human activity in India where sacred plants do not play a role.

\section{Materials and Methods}

Numbers of Purānas were read. In this regard, various libraries were consulted including Central Library, Ranchi University, Ranchi and Kamil Bulke Sodh Sansthan, Ranchi. Oral discussions with well versed personalities in field of Sanskrit and Botany were also made. However, major thrust was on the primary sources-purānas.

\section{Areas of Importance}

Various aspects of importance of plants have been emphasized. Some of these are religious, cultural, ritualistic, environmental and economic importance of plants. However, a few are discussed here.

\footnotetext{
* Assistant Professor, Department of Sanskrit, Ranchi College, Ranchi, Jharkhand-834002, Email: dvd74@rediffmail.com, dvd1309@gmail.com

1 The Purạnas are among the ancient Indian Literature of poetic creativity and said to be the soul of the Vedas. Purānas have served as a perennial source of ideas in their own right. In Indian tradition there are eighteen Mahāpurānas. Besides these there are number of Upapurānas. It is difficult to say definitely when the Purānas first came into being; roughly their period of composition is fixed between 3-12 century CE.
} 


\subsection{Ecological and Environmental importance of Plants}

Plants have been integral part of Indian life and culture. Owing to its importance in day-today human life and environment balance, ancient seers of India did all that was possible to conserve and preserve plants. They developed the concept of tree worship apart from discussing the merits of plantation. How felling or cutting of trees was considered as sin and hazardous have been discussed in ancient Sanskrit literature. As plants are required for healthy environment, thoughts for plant conservation were given prominence in ancient India. If those thoughts are practised in modern era too, problems of environment pollution could easily be met.

For promoting conservation of plants, our ancient seers and poets developed a unique idea of tree worship. This aspect was given prominence in ancient India. Going by Sanskrit Literature, one could easily draw a conclusion that that some trees were abodes of Gods and spirits. It can be stated without an exaggeration that from time immemorial tree worship has occupied an important place in the religious sentiments of Indian people.

3.1.1 Sacredness of plants: As regards plantation and celebration of tree festivals, it is noted that a wise man who perform certain prescribed rites, obtains all his desires (Matsyapurāna, 59.16). He who plants a tree, would live in heaven. He attains great prosperity without any rebirth. The trees alone make a sonless person too have a son (Padma Purāna-1.28.18-22). There are various vratas and festivals related to trees. Some of them are named here such as Arkasaptamī (Padma Purāna, 5.75.86-106), Aśokadvādaśī (Matsyapurāṇa, 81.1-28), Aśokapūrṇimā (Matsyapurāṇa, 184.1), Āmalakyekādaśī (Padmapurāṇa, 6.47.33), Kamalasaptam̄̄ (Matsyapurānạ, 78.1-11), Dūrvāṣtamī (Matsyapurāna, p.137) and Dhātrīvrata (Padma Purāna, 5.58.1-11).
Many plants are considered highly sacred. Plants are often associated with many myth and folklore. The tradition of conserving the plants and the forest wealth was strengthened by social customs and traditions. There were vratas and festivals related to trees. The plants are associated and identified with Gods, planets, months etc. Vāmana Purāna has come up with unique aspect in this regard. It has discussed the divine origin of the plants (Vämana Purāna-17/1-9) as categorised in the table 1.

Table 1

\begin{tabular}{|c|c|}
\hline $\begin{array}{l}\text { Name of the } \\
\text { plants }\end{array}$ & Originated from \\
\hline All the Oșadhis & The dermal hairs of Supreme God. \\
\hline Padma & The naval region of Prajāpati. \\
\hline Kadamba & The palm of Kandarpa. \\
\hline Nyagrodha & The hand of Mannibhadra. \\
\hline Dhattūra & The heart of Maheśvara. \\
\hline Khadira & The mid-region of Brahma's body. \\
\hline Kunda & The palm of Girijā. \\
\hline Palāśa & The right side of Yama's body. \\
\hline Aśvattha & Ravi. \\
\hline Śamī & Kātyāyanī. \\
\hline Bilva & The palm of Lakṣmi. \\
\hline Dūrvā & The tail and back of $V \bar{a} s u k \bar{l}$. \\
\hline
\end{tabular}

Planets were also worshipped in ancient India. These planets were worshipped by specific types of leaves and flowers as mentioned in Table 2 (Bennet, Gupta and Rao, 1992, p. 22):

Table 2

\begin{tabular}{|c|c|}
\hline Planets & Plants used in worshiping \\
\hline Sūrya & Śvetārka (Calotropis procera) \\
\hline Candra & Palāśa (Butea monosperma) \\
\hline Mangala & Khadira $($ Acacia catechu $)$ \\
\hline Budha & Apāmārga (Achyranthus aspera) \\
\hline Guru & Aśvattha (Ficus religiosa) \\
\hline Śukra & Udumbara (Ficus glomerata) \\
\hline Śani & Śamī (Acacia ferruginea) \\
\hline Rāhu & Dūrva (Cynodon dactylon) \\
\hline Ketu & Darbha (Saccharum spontaneum) \\
\hline
\end{tabular}


Bhāgvad Mahāpurāna says that the birth of the trees is verily the most blessed in the world, as it contributes to the well being of all creatures. According to Varāha Purāna, the learned recognize a tree to be like a son because it provides woods for building houses for domestic life, so is shelter for small animals, birds breeding besides providing fruits throughout the year. ${ }^{2}$

3.1.2. Plantation: For conserving plants, Rșis promoted an idea of plantation too. For this they associated many things with plantation. Keeping in view that trees provide food, shade, fuel and wood, Purānas have time and again mentioned that they should be produced, protected and donated to the society. According to Matsya Purāna, planting of trees was a pious action. According to it, he, who plants even one tree, goes straight to the heaven and obtains the highest perfection. ${ }^{3}$ Varāha Purāna adds that just as a dutiful son raises his family by hard effort and austere resolve, so do the trees with their flowers and fruits, raise up from hell their planter. ${ }^{4}$ Vișnu Purāna emphatically discourages inflicting injury to the trees.

3.1.3 Padma Purāna: Discussing the importance of planting trees, Padma Purāna says that it is not possible to know or to narrate the reward earned by that man who plants auspicious trees all around. ${ }^{5}$ The reward that a man would get by planting trees near water is a lakh crore times more than the reward that he would get by planting them somewhere else (Padma Purāna, 1.60.3). Planting even one tree is a yeomen for (Padma Purāna, 1.60.11). He who plants a aśvattha, a picunda, a nyagrodha, ten flowering plants, two-two dadima as well as matulinga and five āmra never goes to hell. ${ }^{6}$ Those who set up orchards or plant trees on the roads, proceed on to Yama's abode without any trouble (Śiva Mahāpurāna-Umā Saṃhitā, 11.6). Those who set up gardens, move on boarding the Pusppaka planes (Śiva Mahāpurāna-Umā Saṃhitā, 11.7). The trees laden with fruits are to be considered golden and best for birds. To protect the garden is to provide pleasure to people. To destroy it is to do harm to others. ${ }^{7}$

3.1.3. Prohibition from felling trees: Not only plantation was promoted in ancient, felling or cutting of trees was highly discouraged and condemned. Felling of plants without permission was considered as a penal offence in ancient India. In the Purānas felling of tree is linked with calamities, disorders and sin, so that people would fear to destroy a tree. The Bhavișya Purāna saysFelling of tree results in the destruction of the family of the person concerned. He also becomes dumb and suffers from diseases (Bhavisya Purāna, 2.16.60). Vāyu Purāna says that whenever people on this earth become greedy and cut off the plants for self use they suffer a lot. Emotions of lust and greed of a human being result in demolition of trees (Vāyu Purāna, 8.83, 87). When those trees got demolished, senses of people got dazed and agitated (Vāyu Purāna, 8.89). Vāmana Purāna says that if the trees, which protect all living beings

\footnotetext{
2 गृहकृत्यानि काष्ठानि क्षुद्रजन्तुगृहं तथा। सत्रनिवर्त्तनं प्रोक्तं भिक्षापात्रै: सभाकृताः।।

फलन्ति वत्सरे मध्ये द्वौ वारौ शकुनादयः। सांवत्सरं पितुर्मातुरुपकारं फलै: कृतम्।

एवं पुत्रसमा रोपा एवं तत्त्वविदो विदुः।। (Varāha Purāna, 170-40-41)

${ }^{3}$ यश्चैकमपि राजेन्द्र वृक्षं संस्थापयेन्नरः। सोऽपि स्वर्गे वसेद् राजन् यावदिन्द्रायुतत्रयम्।। (Matsya Purāna, 59. 17)

4 यथा सुपुत्रः कुलमुद्धरेद्धि यथाऽतिकृत्स्नान्नियमप्रयत्नात्।

तथा प्ररोपा: फलपुष्पभूता: स्वं स्वामिनं नरकादुद्धरन्ति।। (Varāha Purāna, 170. 37)

5 यस्तु रोपयते तीरे पुण्यवृक्षान्समन्ततः। तस्य पुण्यफलं ज्ञातुं कथितुं नैव शक्यते।। (Padma Purāna, 1. 60. 2)

6 अश्वत्थमेक पिचुन्दमेकं न्यग्रोधमेकं दश पुष्पजातीः।

द्वे द्वे तथा दाडिममातुलिड्गे पज्चाम्रवापी नरकं न याति।। (Varāha Purāna, 170. 36)

7 ये च वृक्षाः फलोपेता: ते सुवर्णा: खगोत्तमाः। रक्षां कुर्वन्ति सततं स्वामिनोऽमुत्र चेह च।

तस्य नाशाद् यथा नोऽत्र जातेयं च विरूपता।। (Varāha Purāna, 170. 31)
} 
like mother, are cut then the Earth becomes like a hell. ${ }^{8}$ Cutting a green plant for the sake of fuel is considered as sin (Manusmrti, 11.64). Varāha Purāna (Panchamukhi, 1998, p.304) says that trees should never be cut. If even by mistake or unknowingly one cuts the tree grown in the garden of a city, he will certainly fall into hell after his death. It further adds that if the trees that give shelter to the travellers are cut by a person, he will fall into a hell called 'Asipatravan', wherein he will be tortured by the servants of God Yama. Brahmavaivarta Mahāpurāna says that even Brāhmana, who was considered to be respectable member of the society, was also to be expelled from the society if found guilty of cutting tree, specially aśvattha tree (Brahmavaivarta Mahāpurāna-Gaṇapatikhaṇda, 35.40). According to the Viṣnu Purāna, Śri Keśava is pleased with a person who never fells or hurt trees (Viṣnu Purāna, 3.8.15).

3.1.4. Punishment for cutting trees: Scriptures have prescribed punishments and atonement for cutting trees. This thought developed only to conserve and preserve plants. The Matsya Purāna prescribes various punishments on tree felling and cutting depending upon the gravity of the offence. It states that if a tree with fruits is cut, the offender is to pay the penalty in gold. The penalty will be doubled when the trees on the side of streets, on the borders and on the banks of a water reservoir are cut. For cutting the trees even without fruits the punishment is Madhyama Sāhasa. For cutting plants of category Gulma, Vallī and Latā the penalty prescribed is māsaka of gold. For cutting grass without reason the penalty is Karșapana. The quantity of penalty and the degree of punishment is to be determined by the king after considering various facts like place, time etc. ${ }^{9}$ If branches, trunks and roots are cut without permission, the offender should be fined twenty, forty and eighty gold coins for cutting them respectively (Agnipurāna, 258. 25). By cutting roots of fig tree, a man eternally lives in hell. Men stand by them in the hell called Raurava of fearful sight. ${ }^{10}$

Purānas touched each and every aspect to conserve and preserve trees for ensuring environmental balance. If all that were preached in Purānas are practised with full honesty, proper conservation of plants would become a reality.

\subsection{Cultural Importance of Plants}

Recognising the basic needs of human being, the ancient sages have given fourfold ideal to be striven for by everyone. This is called the Purușārthas or the ends to be striven of life. They are four: dharma (righteousness), artha (wealth), $k \bar{a} m a$ (desires) and moks a (liberation from transmigratory existence). Plants are also related to this purușārthas. Vṛssāyurveda says that trees should be carefully nurtured through their shade, flowers, and fruits as they help immensely in the pursuit of dharma, artha and kama. ${ }^{11}$

Plants are always involved in well being of others. They yield fruit only for beneficence. Trees are like umbrella for those who suffer from scorching sun. They provide shade and bring happiness for the sufferers (Śrimmadbhāgavatmahāpurāna, 10.22.30). The almighty Krṣna says in Śrimadbhāgavatmahāpurāna-

Friends, look at these noble trees, which live entirely for the sake of others,

\footnotetext{
8 फलस्तेयं महापापं फलहीनं तथाऽटनम्। छेदनं वृक्षजातीनां द्वितीयं नरकं स्मृतम्।। (Vāmana Purāna, 61.2)

9 वृक्षं तु सफलं छित्वा सुवर्ण दण्डमर्हति। द्विगुणं दण्डयेच्चैनं पथि सीम्नि जलाशये।। छेदनादफलस्यापि मध्यमं साहसं स्मृतम्। गुल्मवल्लीलतानां च सुवर्णस्य च माषकम्।। वृथाच्छेदी तृणस्यापि दण्डयः कार्षापणं भवेत्। त्रिभागं कृष्णला दण्ड्याः प्राणिनस्ताडने तथा।। देशकालानुरूपेण मूल्यं राजा द्रुमादिषु। तत्स्वामिनस्तथा दण्ड्या दण्डमुक्तस्तु पार्थिवः।। (Matsya Purāna, 227. 91-94)

10 मूलच्छेदेन तस्यैव स च यात्यपुनर्भवम्।। पुरुषास्तस्य तिष्ठन्ति रौरवे घोरदर्शने। (Padmapurāna, 1. 58. 27-28)

${ }^{11}$ अतो धर्मार्थकामानां छायापुष्पफलादिभिः। प्रसाधकतमावृक्षाः पालनीयाः प्रयत्नतः।। (Vrkșäyurveda, 98)
} 
themselves bearing all the rigours of wind, rain, heat, dew etc., but protecting us from them. ${ }^{12}$

Talking about the trees, he further says'How covetable is their life, providing nourishment to all beings who come to them! No one seeking sustenance from them has to go away disappointed, just like needy people seeking help from good men'. (Śrīmadbhāgavatmahāpurāṇa, 10.22.33). Trees fulfil the needs of beings and other creatures with their leaves, flowers, fruits, shade, roots, bark, timber, sweet smelling sap, ashes, wood, and other tender shoots. ${ }^{13}$ The service of the trees in providing fire-wood, sticks for sacrifices like agnihotra, shade for the travellers to rest, nests for birds and medicine for men through the leaves, root and bark is said to be its five sacrifices (pañcayajña). ${ }^{14}$

As far as Artha purșārtha is considered, it has been discussed in a separate subheading entitled 'Economic Importance of Plants'. Kāma purusārtha of trees has also been discussed in Sanskrit Literature. This activity has been described while describing dohada trees. Many trees fall in this category including aśoka, tilaka, bakula, kurbaka etc. The aśoka puts forth its blossom when struck by the foot of a woman preferably the lotus-like foot jingling with anklets of a beautiful woman. In this it is one of the most important trees in the dohada tradition. Dohada literally refers to the cravings of a pregnant woman and in this context the desire of trees, just before they bloom, for some kind of contact with a woman. Women can thus trigger their flowering by a sort of ritual that varies for each tree. For instance, a woman need only glance at the tilaka to make it bud; the campaka succumbs to her laugh, the nameru to her voice and the kurabaka to her embrace. So strong is this tradition that poets count it a wonder when the aśoka and other dohada trees bloom without the instigation of a woman.

As regards Mokșa purușārtha, Varāha purāna says that one who plants and protects the trees full with flowers and fruits for the sake of other beings, certainly attains the last of the four ends of human existence i.e. moks a (liberation) after his death. The planter of trees, according to the prescribed rites liberates the same number of his past and future and attains highest perfection, and is never reborn on earth i.e. attains mokșa (Matsyapurāna, 59. 17-19).

\subsection{Religious and Ritualistic Importance of Plants}

Many of the plants are significant from religious and ritualistic point of view. Some of them are discussed here.

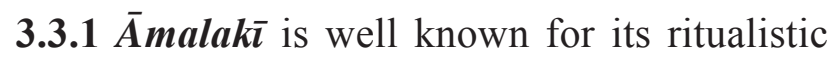
importance. Padma Purāna says long life would be obtained by eating it; religious merit would be accumulated by drinking the juice of it, misfortune would be destroyed by taking a bath after applying its tenacious paste to one's body; and one would get all prosperity. ${ }^{15}$ Skanda Purāna says that wherever one takes bath using dhätri water, whether it is in a tìrtha or in a house, Hari is present there (Skanda Purāna, 2.4.12.121). If the bones in the body of a man are washed with the use of dhātrī while bathing, he will never stay in any womb (Skanda Purāna, 2.4.12.122). It is believed that he whose hair is always well tinged with dhâtrī juice, would never again suck his mothers breast i.e. would never be reborn (Padma

\footnotetext{
12 पश्यतैतान् महाभागान् परार्थेकान्तजीवितान् ।

वातवर्षातपहिमान् सहन्तो वारयन्ति नः।। (Śrīmadbhānavatmahāpurāna, 10. 22. 32)

${ }^{13}$ पत्रपुष्पफलच्छायामूलवल्कलदारुभिः। गन्धनिर्यासभस्मास्थितोक्मैः कामान् वितन्वते।। (Śrīmadbhānavatmahāpurāna, 10. 22. 34)

${ }^{14}$ इन्धनार्थ यदानीतमग्निहोत्रं तदुच्यते। छायाविश्रामपथिके: पक्षिणां निलयेन च।।

पत्रमूलत्वगादींश्च ओषधार्थ तु देहिनाम्। उपकुर्वन्ति वृक्षस्य पज्चयज्ञस्तदुच्यते।। (Varāha Purānan, 170. 38-39)

15 भक्षणे च भवेदायुः पाने वै धर्मसज्चयः। अलक्ष्मीनाशनं स्नाने सर्वेश्वर्यमवाप्तुयात्।। (Padma Purāna, 1.62.4)
} 
Purāna, 1. 62.12). Even a sight of the amalaki tree is considered to be highly fruitful. Lord Viṣnu is pleased with his devotee who utters the name of this tree (Padma Purāna, 1.62.13). Ámalak̄ is an excellent Vaiṣnava tree; one will get the benefit of making the gift of cows merely by remembering it. By seeing it one gets twice the benefit and eating its fruits three times the benefit (Skanda Purāna, 2.4.12.1). In sacrifices to Gods, sages and holy places the offering of dhätri in kärtika was considered sacred (Padma Purāna, 4.22.22). If a man resorts to the shade of dhātri and offers rice balls to Pitrs, the pitrs attain liberation with the favour of Mādhava. ${ }^{16}$ Padma Purāna suggests wearing rosary made of $\bar{a}$ malaki fruits. The man on whose body is seen the rosary made of dhatri fruits is certainly a devotee of Viṣnu (Padma Purāna, 4.22.11). A man can reside in Vaikuntha as many thousands of yugas as the number of days he wears garland of dhātrī in Kali Yuga (Skanda Purāna, 2.4.12.80). By touching āmalakī tree, one's religious merit is doubled, and by wearing it is tripled (Padma Purāna, 6.46.16-17).

3.3.2 Bilva is the embodiment of God Siva himself and is one of the sacred tree symbols of Hinduism. "The bilva tree is the form of Mahādeva (Śiva) and it has been praised even by the Gods". ${ }^{17}$ Instituting Sivalinga beneath bilva is considered as very pious deed. He who does so, and offers prayers and regularly visits there can get rid of even the severe of the severest sin including brahmahatyā (Skandapurāna, 7.2.16.46). The best leaves for worship of Keśava are bilva leaves (Vāmana Purāna, Joshi and Bimali, 2005, p. 497). One who offers prayers to Goddess Pārvatī with bilva leaves with whole devotion gets everything he desires (Vāmana Purāna, 6.251.10). According to Vāyu Purāna, bilva is most suitable for sacrificial purposes (Vāyu Purāṇa, 75.71-72). sruva is an integral part for performing Yajña.
Bhavisya Purāna states that it should be made up of bilva wood (Bhavisya Purāna, 2.19.1).

3.3.3 Khadira: The sacredness of khadira is beyond question. Varāhapurāna discusses the significance of Khadiravana situated in Mathurā. According to it one who visits Khadiravana in Mathurā goes to the abode of Viṣnu (Varāhpurāṇa, 153.42). During śrädha ceremony three pits deserve to be created having three sticks of khadira wood (Vāyu-mahāpurāna, 74.9). Yajña is considered to be an integral part of Indian culture and tradition. The sacrificial post in the yajña is made of khadira wood (Plants: Myths and Tradition in India, 14). A person wishing to subjugate the mind of the sovereign of his country, or an all round improvement of his social status, should pour on the sacrificial fire kindled with twigs of a khadira tree, a hundred thousand libations of clarified butter containing grains of sun dried rice (Agni-purāna, 308.3). The wood of khadira should be used for lighting the sacrificial fire (Matsya-mahāpurāna, 93.27).

3.3.4 Tulasī: Devotees who worship God, take the leaves of tulasi without fail. The Skanda Mahāpurāna suggests that one should worship Vāsudeva with one thousand sprouts of tulasī leaves (Skanda-Purāna, 2.9.29.16). It also adds that he who worships Hari and Hara with bunches of tulasi, is not reborn in any other womb (SkandaPurāna, 2.4.23.13). If a man worships even once with the pure, fragrant and unbroken leaves of glorious tulasi $\bar{l}$, Yama wipes off the sin of that man. Sins are done away with if offering are made with tulasī to Rāma (Skanda-Purāna, 2.5.8.5). Worshipping Viṣnu by tulasī brightness, happiness, fame, wealth, noble family, good character, wife, son, daughter, wealth, kingdom, health, knowledge and special knowledge (of Vedas, Vedāingas, science, Purānas, sacred texts) are in hand birth after birth (Padma-Purāna, 1.60.111-113).

\footnotetext{
${ }^{16}$ धात्रीछायां समाश्रित्य कुर्यात्पिण्डं तु यो नरः। प्रयांति पितरो मुक्तिं प्रसादान्माधवस्य तु।। (Skanda Purāna, 2.4.12.76)

17 महादेवस्वरूपोऽयं बिल्वो देवैरपि स्तुतः। (Śiva Purāna, Vidyeśvara Samhitā, 22. 22)
} 
Śrimaddevībhāgavat Mahāpurāna (9.24.45) has stated the benefit of wearing garland made up of tulasī. Skanda Purāna says that leaves of tulasī are dear to God Viṣnu just like Padmā to Goddess Laksmī who has come out of the ocean of the milk (Skanda- Purāna, 2.5.8.13). Padma Purāna also quotes that tulasī is dear to Viṣnu and he is worshipped with tulasī leaves. By doing so dirt of sins are destroyed in Kali age (Padma- Purāna, 1.61.12-13).

3.3.5 Aśvattha: Srāddha ceremony is related to our Pitras and one has to perform rites and rituals related to this ceremony. According to the Skanda Purāna, for protection of Pitras, an aśvattha tree should be planted with a concentrated mind. It should be nourished like a son or King without any partiality. That aśvattha should be joined in wedlock with samī tree. As long as the earth holds that aśvattha, the family is also sustained. Men who cause that aśvattha plant to grow become rid of sins after falling on the ground i.e. after death; endowed with auspiciousness, they attain excellent womb (Skanda Purāna, 6.215.53-55). While mentioning the due order the vessels for the bali (Oblation) to Pitras, it has been said if the oblation is kept in the cup made of palaśa leaf and offered the benefit of Brahmavarcastva (the Brahminical splendour). In the aśvattha (holy fig tree) it is vasubhāvana (outcome of wealth) (Brāhmānda Purāna, 2.3.11.34-35).

\subsection{Economic Importance of Plants}

Plants have been integral part of an Indian Culture from time immemorial. And, when one talks about the Indian Culture, the role of four Purușārthas i.e. dharma, artha, kāma and mokșa in shaping the destiny of human being cannot be ruled out. Of these Purusāarthas, artha has special significance as it is related to economic activities. Here one would be astonished to know that here too plants have vital role to play. Many of the industries are associated with plants with one way or the other.
3.4.1 Garments: Garment industry was in quite advance stage in ancient India. Plants had major role to play in enriching this industry. Vāyu Purāna refers that plants as the prime source of garment products (Vāyu Purāna, 8.88). Another important Purāna, Vāmana Purāna (14.63) hints towards making garments from kārpāsa, cīnānsuka (Vāmana Purāna, 11.59) and muñja (Vāmana Purāna, 11.45). Kūrma Purāna states that 'mekhala' (a garment to cover waist and downwards) should be made with either 'muñja' or 'kuśa' (Kurma Purāna, U-12.14). Garments made of ' $k \bar{a} r p \bar{a} s a$ ' and 'kașāyaka' have also been discussed in this Purāna. It is worth mentioning that paste of śveta and rakta candana was used as cosmetic and bathing material in Purānic age (Vāmana Purāna, 51.64, 67.36).

3.4.2 Agriculture: Agriculture (Sanskrit; $k r s ̦ i$ ) is an important aspect related to plants and literature is replete with the references on $k r s i$. Vedic seers knew that agriculture was the only option for food security. The agriculture has been the chief source of livelihood to people in India. Agriculture depends on many factors like soil, farmers, seeds, farming techniques, agricultural implements, irrigation, manures etc. In Purānās, the agriculture was considered to be best among all occupations as it was very basis of leading the life with happiness and prosperity.

According to the Mārkaṇdeya Purāna (46. 65-75), Brahmā was regarded as the first inventor of agriculture. According to this, in the beginning of the creation of the earth, the soil yielded almost all type of corns, vegetables and fruits etc. However, as the time passed, the soil became unproductive. Thereafter, Brahmā churned the soil, and got various kinds of seeds. These seeds on their own accord started giving corns, fruits etc. Later on Brahmā realized that these seeds were also not growing properly. Then He brought the agriculture into practice. Seeing the ability of different classes of the people in the society he initiated one class of the people to do this 
profession of agriculture. Since then the agriculture depended on human toil.

However, according to the Viṣnu Purāṇa and Śrimad Bhāgvad Mahāpurāna (4.18.29-32), a king named Prthu, the son of a king Vena was regarded as the inventor of agriculture. Prthu may be considered as a king who effectively brought the agriculture into practice.

\subsection{Horticultural Importance}

Horticulture is related to intensive plant cultivation meant for human use. It is primarily related to gardening both at individual and institution level. It includes both food (fruits and vegetables etc.) and non-food (flowers, trees and medicinal herbs etc.) crops. Horticulturists apply their knowledge and skills especially for plant propagation, cultivation, resistance to insects, diseases, and environmental stresses. It has also to deal with germination of seeds, plant propagation, nutrition and manuring of plants, growth and conservation of plants. It can undoubtedly be said that that horticulture happens when people are in intimate, intensive contact with plants. It is the interface between people and plants.

Purānic literature is replete with the facts relating to the plants. Planting trees in gardens for religious and social service has been allotted a special place in the construction of human settlements. According to the Purānas, attached to every house there should be a vrkșavatiki puspavātiā etc. where fruit trees and flowering plants could grow. As in all hot climates an expanse of water was an almost essential feature of the Purānic gardens, they also contained artificial lakes and pools.
3.5.1 Trees Plantation: Purānas have discussed about the effects of different trees planted around the dwelling of man. According to it the trees known as plaksas, should be planted to the north of the dwelling house, the vamas on the east, the mangoes on the south, and the aśvattha on the west. ${ }^{18}$ The Purâna further adds that thorny shrubs should be so planted as to edge the southern boundary of the ground of a house. The flower garden should be laid out adjoining a dwelling house, or blooming plants of tila should be cultivated therein. ${ }^{19}$ The Agni Purāna suggests that the trees should be planted after having worshiped the Brähmanas and their sovereign, the moon god, and under the auspices of the asterisms presided over by the wind god, Prajāpati, and the god Viṣnu respectively (Agni purāna, 282. 3).

Regarding the plantation of trees and their maintenance, the Agni Purāna says that trees such as arișta, punnāga, śirīṣa, priyañgu, aśoka, kadalī, jambū, bakul, dadima, or any other tree planted in a garden should be watered, each morning and evening, during the summer months, and on each alternate day during winter, and at the break of dawn during the rains when the earth would be dry and require watering. ${ }^{20}$

It adds that trees planted in rows, twenty cubits apart, should be deemed as the best planted, while those having a space of sixteen cubits should be deemed as ranking second best in fruitfulness. Trees should be transplanted twelve times. Nor should they be planted too close or adjoining each other, in which case branches that touch one another, should be lopped off with a chopper, as otherwise they would bear no fruits. ${ }^{21}$

\footnotetext{
18 .. ... ... ... ... ... .. प्लक्षश्चोत्तरतः शुभः। प्राग्वटो याम्यतस्त्वाम्र आप्येऽश्वत्थः क्रमेण तु।। (Agni purāna, 282.1)

19 दक्षिणां दिशमुत्पन्नाः समीपे कण्टकद्रुमाः। उद्यानं गृहवासे स्यात्तिलन्वाप्यथ पुष्पितान्।। (Agni purāna, 282.2)

${ }^{20}$ अरिष्टाशोकपुन्नागशिरीषा: सप्रियड्ग्गवः।। अशोक: कदली जम्बूस्तथा बकुलदाडिमाः।

सायं प्रातस्तु घर्मत्तो शीतकाले दिनान्तरे।। वर्षारात्रौ भुवः शोषे सेक्तव्या रोपिता द्रुमाः। (Agni purāna, 282.6-8)

${ }^{21}$ उत्तमा विंशतिर्हस्ता मध्यमाः षोडशान्तराः।। स्थानात्स्थानान्तरं कार्यं वृक्षाणां द्वादशावरम्।

विफला: स्युर्नरा वृक्षा: शस्त्रेणादौ हि शोधनम्।। (Agni purāna, 282.8-9)
} 
3.5.2 Fertility \& Treatment of Seeds: To increase the fertility of the seeds they are treated before sowing.

Arthaśāstra: According to the Arthaśāstra, seeds are to be soaked in dew and dried in the heat for seven days; those of pulses for three days and nights or five; stalks that serve as seeds are to smeared at the cut with honey, ghee and pig's fat mixed with cow-dung; bulbous roots to be smeared with honey and ghee; and stone like seeds to be smeared with cow-dung.

Vrkșāyurveda: The Vrkșāyurveda of Surāpala deals with the treatment of seeds in some details. According to it, seed is extracted from dried fruits which become ripe in the natural course and season. It is then sprinkled with milk and dried for five days. It is then smoked with mustard seed mixed with vidanga. ${ }^{22}$ Seeds sprinkled with milk, smeared with mustard and ash of tila and brhati, rubbed with cow dung, and smoked with marrow sprout in no time. ${ }^{23}$ Seeds sprinkled with milk, rubbed with cow dung, dried and profusely smeared with honey and vidanga definitely sprout (Vrkṣāyurveda, 54).

Mānasollāsa: Mānasollāsa also discusses the process of seed treatment. According to it, the first method is employed for the seeds of all kinds of trees. According to this method, the ripe fruits are first dried in Sun. Then they are kept covered with cow-dung for five days. They are perfumed with the vidanga and the clarified butter (MānasollāsaBhüdharkrida, $6-8)$. The other method is a special treatment given to the milky trees. According to this method, the seeds are soaked in the cow's milk continuously for ten nights. They are coated with the cow-dung and mixed with the ashes of vyāghr and with ashes of barley and wheat (MānasollāsaBhüdharkridā, 9-10). Sowing being an important process in cultivation, it was given serious attention and care.
Brhatsamhitā: Various Sanskrit texts have described the fact that plants were propagated in ancient India by cutting and grafting. According to the Brhatsamhitā, grafting may be done in respect of the Jack tree, aśoka, plantain, eugenia, lemon, pomegranate, grape, pālìvata, mātulunga and jasmine creeper by smearing a branch with cow-dung and transplanting it on the branch of another; or it may be done by cutting off the trunk of a tree and transplanting it like a wedge on the trunk of another tree. Here the part when the junction is affected must be covered with coating of mud (Brhatsamhitā, 55. 4-5). The grafting should be done in Siśira season for those plants which have not yet got branches; in the Hemanta season for those that have grown branches; and in rainy season for those that have large branches. The particular direction of the tree that is cut off should be kept up in grafting also (Bṛhatsam hita 55. 6). Vrkșāyurveda has also discussed the plant propagation through cutting and grafting.

3.5.3 Sowing of Seeds: Rainy season is the best time recommended for sowing all types of seeds and planting trees, etc. Autumn and spring are mediocre seasons for the purpose (Viśvavallabha, 4.1). Winter and summer are both contraindicated for plantation. A senior planter may plant trees if advised by some people. All seasons are equally good for plantation when extra effort is put on watering (Viśvavallabha, 4.2). Even a well grown crop does not yield full returns if grass is not weeded out. The yield is considerably reduced due to the grass (Krși Parāśara, 189). Crop from which grass is weeded out in Śrāvaṇa and Bhādrapada, doubles itself although full of grass later (Krṣi Parāśara, 190). Weeding should be done twice in Áśvina. Thus unripe crop grows like black gram (Krṣi Parāśara, 191). Hence every effort should be made to weed out grass. Farms free from weeds fulfil wishes of the farmers (Kṛsi Parāśara, 192).

\footnotetext{
22 यथर्त्तपक्वात् फलतोविशोषिताद्विकृष्यबीजं पयसा निषिच्या।

विशोषितं पझ्चदिनानि सर्पिपषां विडड्गमिश्रेण च धूपयेत्ततः।। (Vrksāyurveda, 52)

${ }^{23}$ क्षीरनिषिक्त बीजं बृहतीतिलभस्मसर्पिषां लिप्तम्। गोमयमृदितमथोप्तं सद्यो जायेत धूपितं वसया।। (Vrkssäyurveda, 53)
} 
3.5.4 Growth of Plants: The process of good growth of plants has been well discussed in Agni Purạna. It says that a good growth of trees is secured by sprinkling them with the washing of fish. Fish and meat, powdered and mixed with a quantity of pulverised vidanga, should be sprinkled over a tree by way of a pregnancy present, or for the purpose of curing it of all distempers (Agni Purāna, 282.13).

The Krși Parāsara recognizes the importance of manure for crops and says that without manure the paddy simply grows up, but does not yield any fruit. ${ }^{24}$ Kāśyapīyakrșisūkti says that cow-dung, goat-dung, and compost should be spread on the land to increase its potency (Kāśyapīyakrșisūkti, 6.266). Planting should be done line by line in the fields which have already received sufficient manure of goat-dung or cowdung or the tendrils of creepers (Käśyapīyakrșisūkti, 6.435-36). Trees do not produce fruits and flowers merely for being planted; hence we are going to state the rule relating to the nourishment of plants as framed by the sages. ${ }^{25}$ If one applies powdered oil-cakes of white mustard or sesamum at the root of kharjūra, bilva and lakuca trees-all these three grow; and the mango tree grows if it is watered with water in which husks are soaked; äirāvata and niculapatra grow by simple watering, but they grow also if watered with flesh and paddy washing (Upavana Vinoda, 9.148). Mango trees bear very fragrant and sweet fruits at an early date if they are watered with decoction made up of milk, pañcapallava, i.e. leaves of àmra, aśvattha, vama, plakșa and yajñadruma, together with the fat of deer, boar, jackal, elephant, horse etc. ${ }^{26}$ Any fruitful tree verily bears very sweet fruits if any experienced or wise man waters its roots with milk (Upavana Vinoda, 9.170). One should boil the flesh, fat and marrow of deer, pig, fish, sheep, goat and rhinoceros in water, and when it is properly boiled one should put the mixture in an earthen pot and add into the compound milk, powders of sesamum oil-cakes, māsa boiled in honey, the decoction of pulses, clarified butter and hot water. There is no fixity as to the amount of any of these elements; when the said pot is put in a warm place for about a fortnight the compound becomes what is called kunapa water which is very healthy for plants in general (Upavana Vinoda-9/171-174). In order that the trees should grow and produce abundant fruits, King Someśvara recommends various processes (Mānasollāsa-Bhüdharkriḍā, 35-86) to be employed.

3.5.5 Disease of Plants: As regards the various plants diseases the Agnipurāna states that in cases where barrenness would be apprehended, the leaves and branches of a tree should be sprinkled; the leaves and branches of a tree should be sprinkled over with a solution of cold water, saturated with vidang a, clarified butter, pulverized mudga, māsa and kulattha pulse. Similarly a tree sprinkled with a solution of cold water, and clarified butter, becomes laden with abundant fruits and blossoms. ${ }^{27}$

Viṣnudharmottara Purāna: Viṣnudharmottara Purāna has also come up with certain description in this regard. It says that if the trees get some disease, first of all they should be watered with cold water and pasting cow dung, ghee and mud (Viṣnudharmottara Purāna, Part II, 30.18). The sprinkling with cold water which have fish is good for mango tree (Viṣnudharmottara Purāna, Part

\footnotetext{
${ }^{24}$ ततो वपनकाले तु कुर्यात् सारविमोचनम्। विना सारेण यद्धान्यं वर्धते फलवर्जितम्।। (Krși Parāsarara, 111)

${ }^{25}$ फलकुसुमसंपदुचिता रोपणतो भवति केवलान्न यतः। पोषणविधिमथ संमतमनोकहानामतो वक्ष्ये।। (Upavana Vinoda, 9.147)

${ }^{26}$ कुरङ्गकिटिसारङ्गशृगालाश्वादिमेदसा। क्वथितेन सदुग्धेन पझ्चपल्लववारिणा।

कृतसेको भवेदाशु सहकारोतिसौरभः।। (Upavana Vinoda, 9.150)

${ }^{27}$ विडड्गघृतपङ्काक्तान्सेचयेच्छीतवारिणा। फलनाशे कुलत्थैश्च माषैर्मुद्गैर्यवैस्तिलैः।।

घृतशीतपयः सेक: फलपुष्पाय सर्वदा। आविकाजशकृच्चूर्ण यवचूर्ण तिलानि च।। (Agni Purāna, 282.10-11)
} 
II, 30.23). The saptaparna tree becomes attractive with the sprinkling of milk. (Viṣnudharmottara Purāna, Part II, 30.28). For buds of mallika fragrant water is most beneficial (Viṣnudharmottara Purāna, Part II, 30.30). For kharjura, coconut, bamboo and kadali trees, the sprinkling and salt with water causes their growth. The vidariga with rice and flesh is good for all trees (Viṣnudharmottara Purāna, Part II, 30.3132).

Upavana Vinoda: Substances of pungent, bitter or caustic tastes are destructive of the windy humours of trees; and those having bitter, hot, salty and acid juice are destructive of biles, and those with graceful, sweet, acid or salty juice are destructive of phlegm (Upavana Vinoda, 13.180). The affectations of windy humour is alleviated through the application of the graceful things like clarified butter mixed with flesh juice; the affectation through the bile is alleviated through the application of things that are cold and graceful mixed with water, and affectations through phlegm is modified through application of acid things mixed with hot water, or through pungent and bitter things (Upavana Vinoda, 13.181).

Vrkșāyurveda: Diseases caused by imbalance of $v \bar{a} t a$ can be cured by flesh, marrow, and ghee. The sprinkling of kunapa water also removes all the disorders caused by the vāta element (Vrkșāyurveda, 185). The diseases of vāta type can be quickly warded off by liberal fumigation of the mixture of the fat of the hog, oil of Gangetic porpoise, ghee, hemp, hair of horse, and cow's horn-boiled and set to a decoction (Vrksāayurveda, 186). Trees suffering from wind-related diseases should be sprinkled with bitter juices of plants to generate heat in plants with watery decoction of oily flesh, or should be sprayed with powdered cow-dung (Viśvavallabha, 8.10).

The diseases of the kapha type can be overcome with bitter, strong, and astringent decoctions made put of Pañcamūla with fragrant water (Vrksāayurveda, 187). For warding off all kapha type of diseases, the paste of white mustard should be deposited at the root and trees should be watered with a mixture of sesame and ashes (Vrkșāyurveda, 188). Pungent, hot, dry and bitter decoctions and juices quickly set right the phlegm disorder. A tree suffering from phlegm gets relief if sprinkled with warm water, too (Viśvavallabha, $8 / 20)$. A wise person should treat all types of trees affected by the pitta type of diseases with cool and sweet substances (Vrkșāyurveda, 190). When watered by the decoction of milk, honey, yaștimadhu and madhüka, trees suffering from pitta type of diseases get cured (Vrksāyurveda, 191). Watered with the decoctions of fruits, triphala, ghee, and honey the trees are freed of all diseases of the pitta type (Vrkcāyurveda, 192). Trees suffering from damage due to frost or scorching heat should be externally covered. Sprinkling with kunapa water and milk is also advisable (Vrkșāyurveda, 199). One should take up the ashes of trees struck by lightning, throw the same around other trees and this will ensure the latter against the cold. These have power to allay even burning fire (Upavana Vinoda, 8.79). A frost burn tree shoots forth if a paste of aikola, milk, clarified butter, and honey is applied to the root, if fresh soil, cow dung and oil are provided, if sprinkled and smeared with tila and milk and sprinkled in the end with water (Viśvavallabha, 8.48). The trees can be protected from snowfall if the pits are covered with the soil brought from the pit of the tree hit by the lightning (MānasollāsaBhüdharkridā, 27). For warding off damage from hail storm, cooked rice mixed with curd and rock salt should be scattered on the ground surface (Mānasollāsa-Bhūdharkriḍā, 28). A tree struck and burned by lightning does produce shoots in no time if it is liberally sprinkled with powdered madhūka, mudgāa, tila and māsa gram mixed in milk along with yava (Viśvavallabha, 8.53). When

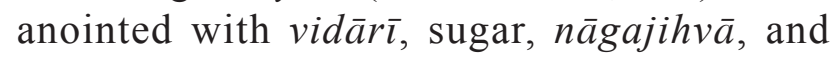
Sesame mixed together and when sprinkled with milk-water, trees struck with lightning put forth 
healthy sprouts (Vrksāyurveda, 206). The broken trees should be smeared with the paste of bark of plakṣa and udumbara mixed with ghee, honey, wine and milk and the broken part should be firmly tied together with the rope of a rice stalk. Fresh soil should then be filled in the basin around the tree, sprinkled immediately with the milk of buffalo and flooded with water. Thus they recover (Vrksāyurveda, 200-201). One should besmear the branch of tree broken by wind with the barks of plaksa, arka and udumbara trees pasted in ghee, honey and beeswax mixed with milk; should set it the broken parts as before, and tie it to a post fixed nearby, and apply finely powdered earth to the fractured part. And if sprinkled with milk over and over again, and the plant watered at the root, the tree gets round and produces abundance of flowers and fruits (Upavana Vinoda, 13.186). If the branches fall off, the particular spot should be anointed with the mixture of honey and ghee and sprinkled over by milk and water so that the tree will have its branches reaching the sky (Vrkșāyurveda, 203). If the trees are dried due to bad soil, the original soil from the root should be removed and it should be replaced by healthy soil and milk water should be sprinkled over it (Vrksāayurveda, 208). The wounds of the trees are healed by the treatment of anointing with the paste of the bark of nyagrodha and udumbara, cow dung, honey and ghee (Vrkșāyurveda, 210). After trees show symptoms of ulcer, the trees should be treated. At the outset the trees should be cleared of ulcers and the like (i.e. whatever is colourless and wet) with a knife. Then a paste made of vidanga, ghee and silt must be applied to those parts and they should be sprinkled with water and milk (Brhat Samhitā, 55.15). Tender plants suffering from excess watering should be scratched with nails, uprooted, and every root should be smeared with the mixture of honey and vidariga and then should be watered (Vrkssāyurveda, 219). Triphalā and kuberākṣi provided at the root followed by watering and smearing with paste of vidainga, Ingud $\bar{l}$, and honey are measures recommended for the treating the indigestion caused by excessive intake of food (manure) (Viśvavallabha, 8.29). When a tree suffers from incapacity to digest water, it is always pale, devoid of leaves, full of ants and the smell of fish, and in places devoid of barks, the following treatment has to be adopted in this case: one should strike at the root of the tree suffering from indigestion to draw the poisonous sap out of the trunk, apply to the affected place a paste of honey, vidanga powder and sesamum and cover it with earth and sprinkle it with water and milk. The atrophy of a tree is radically cured if it be besmeared with the said paste after it has been sprinkled with sugar and sesamum mixed with milk and water and then fumigated (Upavana Vinoda, 13.191-193). Applying the paste of sugar, tila and cow's milk and sprinkling the same, mixed with water all the dehydrated trees are completely cured (Viśvavallabha, 8.70). The trees which get dotage through repeated production of fruits and flowers, when bathed (treated) in kunapa water and milk again and again, do surely bear fruit. (Upavana Vinoda, 13.189). When the fruits of a tree are destroyed prematurely, it should be watered with milk that has been cooled after being boiled, with horse gram, black gram, sesamum and barley. Being treated thus, it will have abundant flowers and fruits (Brhat Samhitā, 55.16). One should carefully protect trees against destructive influence of dew, strong wind, smoke, fire and spiders (Upavana Vinoda, 8.77).

3.5.6 Pests and their management: During the long history of crop cultivation in India, insect pests have always been a biotic constraint. There are descriptions regarding pests and their management in Sanskrit texts. Field pests and store house pests of crops were evidently as familiar and dreaded enemies of the farmer, then as now. Large and visible pests like beetles, bugs and caterpillars, and invisible enemies like fungi and bacteria attacked crops on the field. In Rgveda, it is mentioned that several insects and pests used 
to destroy the standing crops. One should do well to realise that worms are at the roots of plants affected with tubercles, or of plants for the paleness of buds and flowers of which no other particular cause can be assigned; and one should do well to root out these worms with care. If fresh urine of cows, clarified butter, vidanga, mustard and sesamum are mixed together and applied to the trunk, then fumigated and watered with milk and water, these plants grow (Upavana Vinoda, 9.183).

Destruction of plants by fungi and pestiferous insects, are referred to in ancient literature. For the first time, in Vedic literature, we find a hymn in Atharvaveda which refers to the destruction of corns by vermins, such as the tarda (borer), jabhya (snapper), the upakavasa (a noxious insect injurious to health), vyadvaras (rodents), samanka (hook), the mole, and such other devourers of corn. There are mantras in Atharvaveda, which say-

\begin{abstract}
"O pleasant man and woman! Kill injurious rat, boring beast and cut off their head and cut their ribs. Bind fast their mouths to enable them so that they do not eat barley and thus make safety of crop. Let the injurious insects, birds and locusts, noxious insects and grass hoppers fly away devouring not and injuring nor the corn like the priest who does not accept uncleaned things for oblation. Let the injurious insects, the beasts destroying crops, the boring beasts, realize that we destroy all those animal who eat and spoil our crops be they in the wood or be they piercing ones". (Atharvaveda, 6.50.1-3)
\end{abstract}

Commenting on these mantras, Sāyana adds more names of these pestiferous insectsmūṣaka, śalabha, patanga, tittibha, kìma, komika, harina, salyaka, godh etc. These insects injure young shoots. It also informs that wild animals destroy the plants with their teeth. Tarda is the bird known as wood-pecker. This word has been used generally for the birds who are harmful for crops. The word patanga has been used for locusts.
Jabhya is the insect called weevil which eats into the grains. It eats up barley etc. Upakvasa is the name of a poisonous insect that eats away grain or seeds. Their killing has been advised. Trsțambha is a insect with sharp teeth.

Viśvavallabha: Viśvavallabha says that if without any disturbance in the three elements if a tree loses its shoots, branches dry at the end, barks fall off, leaves lose colour and trees appear very sickly, the cause should be traced to insects (Viśvavallabha, 8.35). Insects are of two types, external and internal. Some external insects lives on bark while others on leaves, flowers, and fruits. (Viśvavallabha, 8.36). An insect named kāndāraka (borer) lives in between the root and the branches. The tree can be destroyed when infested by it. As such it should be treated (Viśvavallabha, 8. 37). Viśvavallabha says that insects originate from soil, water and dohada (a special kind of manure. It is used by the experts to produce out of season, flowers on the trees, creepers and bushes etc.) (Viśvavallabha, 8.38).

Vrkșāyurveda: If the farm is infested with rats, etc. a certain mantra has to be written on the plantain leaf with lac dye and should be kept at the centre of the field in the triangle (Vrksāyurveda, 161-162). The mantra has the meaning-Om Svasti! (Let peace prevail). The Lord of Hanümān from Kiskindhā, whose feet are ever victorious, who has displayed his valor in great disasters and by capturing the Sun, who is the Lord of lords, commands the rats, the shrews, grasshoppers, etc. in this particular land, "Leave this land and go elsewhere immediately on seeing this order of the king, otherwise the king will use powerful like the thunderbolt, to kill, burn, and destroy all of you. Hum Pham Svāhā. After writing this mantra on a leaf and having recited it, the leaf should be buried in the ground. This will destroy all insects, kites, rats, ants, etc. (Ṿ̣sāâurveda, 163).

To remove insects both from roots and branches of the trees, wise man should water the 
trees with cold water for seven days (Vrkșāyurveda, 193). The worms can be overcome by the paste of milk, kunapa water, and cow dung mixed with water and also by smearing the root with the mixture of white mustard, vacā, kuștha and ativișa (Vrkșāyurveda, 194). The worms accumulated on trees can be treated quickly by smoking the tree with the mixture of white mustard, rāmatha, vidanga, vacā, usana $\bar{a}$, and water mixed with beef, horn of buffalo, flesh of pigeon, and the powder of billāta (Vrkșāyurveda, 195). Anointing with vidanga mixed with ghee, watering for seven days with salt water, and applying ointment made out of beef, white mustard and sesame destroy the worms, insects etc (Vrksāyurveda, 196). Creepers eaten away by insects should be sprinkled with water mixed with oil cake. The insects on the leaves can be destroyed by sprinkling the powder of ashes and brick-dust (Vrkșāyurveda, 197). A wound caused by insects heals if sprinkled with milk after being anointed with a mixture of vidanga, Sesame, cow's urine, ghee and mustard (Vrkșāyurveda, 198).

The worms accumulated on the trees can be treated quickly by smoking the tree with the mixture of white mustard, rāmatha, vidanga, vacā, usana, and water mixed with beef, horn of buffalo, flesh of pigeon, and the powder of bhillata (Vrksāyurveda, 195). A powder prepared from barks of aragvadha, arișta, karañja, saptaparṇa, and vidanga soaked for a night in cow's urine and pasted on the affected parts of the tree frees them from external insects. (Viśvavallabha, 8/39). A paste made from the mixture of vidanga, siddhārtha, trikatu (this is an aggregate of three pungent substances like ginger, black and long peeper or like dry ginger, pepper and pippali $)$, cow's urine, bhallata and vaca applied to the tree destroys insects living in between the branches retrieving the colour of the barks (Viśvavallabha, 8.40). Fumigation by the mixture of cow's horn, bhallataka, nimbu, mustā, vacāa, viḍinga, ativāsa, karañja, sarja, siddhārthaka and sinduvāra draws outs insects from within trees (Viśvavallabha, 8. 41).

Applying paste of dung of cat, jackal, and hog mixed in siddhārtha and cow's urine, draws out insects hidden inside the trees and fumigation by the same mixture along with clarified butter wipes out the external ones (Viśvavallabha, 8.42). Fumigated with a mixture of nimba, siddhārtha, vaca , vidanga, hingu and barks of arjuna, in combination with tila, milk and water and sprinkled with mixture of milk and water a tree infested with insects is freed from the pest and once again becomes green with a new growth of branches and tender leaves. (Viśvavallabha, 8. 43). All the trees can be relieved from insects by sprinkling water mixed with fruits and bark of ingudi, and raw sugar. By applying a paste of milk, clarified butter, raw sugar, and ingudi or by fumigating with the same and by tying dog's bone on them will rid the trees and insects (Viśvavallabha, 8.44). When palāśa tree, planted in between other trees, bears fruits, it prevents the water related diseases and water borne insects from infecting other trees as do aśka (Viśvavallabha, 8. 45). In between smaller trees, the wise planter should plant densely in the field śatapuspa and kuberākssi as a result of which he can get rid of insects (Viśvavallabha, 6. 5). All types of worms are destroyed if one applies to the roots of trees the barks of karañja, aragvada, arișta, saptaparna-pasted in the urine of cows together with vidanga and musta (Upavana Vinoda, 9. 184). Two methods are given for the destruction of worms and insects in Mānasollāsa. Firstly, the trees should be perfumed with the smoke produced by burning niśa , vidanga, siddhāratha and arjuna flower mixed with the flesh of rohita fish. Besides killing insects and worms, it also helps in the luxuriant growth of flowers and fruits (Mānasollāsa-Bhüdharkridā, 29-30). Secondly, the insects and worms can also be killed if the trees are perfumed with the smoke caused by burning of vidanga, hingu, sindhura, 
marica, ativisa, vaca, bhallātaka and the horns of the buffalo mixed together in equal quantities. This process also destroys all the diseases of plants (Mānasollāsa-Bhūdharkridā, 31-32)

Rgveda: In the Rgvedic period, the cultivators kept away birds from corn fields by making din and noise (Rgveda, 10.68.1). In Rgveda a prayer is offered to save the people from the jaws of famine (Rgveda, 8. 118). Indra is invited to set the people free from famine (Rgveda, 8.55). Ancient Indians also made scare crows to scare away birds from standing crops. Towards harvest time, they used to set tracks, fix sticks and snares to trap animals who come to devour their standing crops. Besides, the animals were frightened of by a shadow figure made of straw which was placed in the field. The Mahäbhärata refers to the employment of a state functionary for the protection of agriculture, for, it is stated that if the cultivators felt a sense of insecurity, the king was to earn ill fame thereby (Mahābhārata-Sabhāprva, 80). Thus the monarchs generally exercised vigilance on the development of agriculture by adopting sound policy.

Matsya Purāna: Going by the Matsya Purāna, it becomes clear that Purānic seers knew techniques for promoting inflorescence and fruiting. It saysThe country where the Airāvatī river has its origin there are sweet smelling lotuses of various colours. Some of the blooming lotuses looked like the rising Sun, some like the Moon and the Sun. Some looked like bright gold, and some resembled the śan flower. The place was full of growing lotuses, of which some looked like the leaf of siriș $a$, some having five colours, others many (Matsya Purāna, 118. 39-41).

Purānic seers not only focused and promoted plantation but also tried to ensure their protection. They prescribed punishments for those who were involved in felling trees. Kürma Purāna is of the view that one should not cut trees known as chaitya. ${ }^{28}$ A person who steals even grass, vegetable he surely falls in hell (Kürma Purāna, Uttarārdha, 16.2). A person who receives the flower, vegetables, water and firewood, besides fruit and roots without being specifically given, it amounts to theft. ${ }^{29}$ The Brāhmanas can take the flowers for the adoration of the Gods, but even the flowers should not be collected without the permission of the owner (Kürma Purāna, Uttarārdha, 16.8). For felling or cutting or injuring fruit giving trees one should chant $R k$ for one hundred times as an atonement to get rid of his sin. According to Agni Purāna stealing flowers, fruits and wood is immoral act which brings sin to the concerned person. ${ }^{30}$

Purānas promoted plantation in a unique way. They came up with descriptions which dealt with the fruits of planting trees. Brahmavaivarta Purāna says-

In case of the coconut trees are planted in
the $\bar{a}$ śrama, the householder achieves
riches, these trees when planted towards
the east or north east bestows son to the
householder. The mango tree bestows
welfare all round. In case it is planted to
the east of the house, the householder
achieves enough of riches and it bestows
welfare everywhere. The trees of wood-
apple, jack fruit, the lemon and jujube, if
planted on the southern side, the
householder gets riches all the times. The
prosperity of householder increases with
them. The trees of sāla fruit, banana,
myrobalon, when planted in the southern
side they increase the friends. They are
auspicious for all sides, the betel nut tree
when planted on the southern side
provides the householder with riches, son
and fortunes, in case they are planted in
the west, they bestow pleasure and in case
they are planted in the north east, they

\footnotetext{
${ }^{28}$ चैत्यं वृक्षं न वै छिन्द्यान्नाप्सु ष्ठीवनमुत्सृजेत्।। (Kürma Purāṇa, Uttarārahha, 16/79)

${ }^{29}$ पुष्पे शाकोदके काष्ठे तथा मूले तृणे फले। अदत्तादानमस्तेयं मनुं प्राह प्रजापतिः।। (Kürma Purāna, Uttarārdha, 16.7)

30 फलैध: कुसुमस्तेयमधैर्यं च मलावहम्। (Agni Purāna, 168. 40)
} 
bestow welfare all round. Campaka planted anywhere is beneficial to all and sundry. ${ }^{31}$

Padma Purāna: Padma Purāna has also described the fruits for planting various trees. It says-

By planting an aśvattha tree one would become wealthy. The aśoka tree destroys grief. The plaksa tree is said to give the fruit of a sacrifice; the ksira tree is said to cause long life. Jambuki gives daughters; dadima gives a wife. Aśvattha leads to destruction of diseases; palāśa takes one to Brahman. The planting of ankola trees leads to expansion of the family. Health is caused by the planting of khadira tree. The sun is ever pleased with the nimba shoots. God Śiva is pleased when śri tree is planted; and Pāravati is pleased with the red lodhra being planted. The celestial nymphs are pleased with the planting of simśap $\bar{a}$, and best gandharvas with the kunda tree. One would get group of servants of one plants tintidika tree. Candana, and panasa also gives religious merit and wealth. Planting of campaka gives good fortune. Planting of vakula expands family. Planting of the grapecreeper makes one have an all-beautiful wife. Similarly planting of koli causes sexual enjoyment; planting of ketaki destroys one's enemies. ${ }^{32}$

3.5.6 Consecration of trees: Consecration of trees has been unique concept of Purānic age. According to the Purānas, it imparts enjoyment in this world and salvation in the next. Water containing solution of the drugs known as sarvausadhi should be poured over the heads of the trees from whose boughs garland should be hung down, and which should be plastered over with rice paste and covered over with pieces of cloth. The ceremony of karnvedha (perforation of the balls of the ears) should be performed up to them, with needles made of gold. ${ }^{33}$ And on the masonry platform around them, the adhivāsa rite of the pitchers should be celebrated. Offering should be made in honour of the God Indra and his companion deities, and homa ceremony should be performed unto vanaspati. The Earth Goddess should be

\footnotetext{
${ }^{31}$ आश्रमे नारिकेलश्च गृहिणां च धनप्रदः। शिबिरस्य यदीशाने पूर्वे पुत्रप्रदस्तरुः।। सर्वत्र मङ्गलार्हश्च तरुराजो मनोहरः। रसालवृक्षः पूर्वस्मिन्नृणां संपत्प्रदस्तथा।। शुभप्रदश्च सर्वत्र सुरकारो निशामय। बिल्वश्च पनसश्चौव सुरकारो निशामय।। प्रजाप्रदश्च पूर्वस्मिन्दक्षिणे धनदस्तथा। संपत्प्रदश्च सर्वत्र यतो हि बर्धते गृही।। जम्बूवृक्षश्च दाडिम्बः कदल्याम्रातकस्तथा। बन्धुप्रदश्च पूर्वस्मिन्दक्षिणे मित्रदस्तथा।। सर्वत्र शुभदश्चैव धनपुत्रशुभप्रदः। हर्षप्रदो गुवाकश्च दक्षिणे पश्चिमे तथा।। ईशाने सुखदश्चैव सर्वत्रैव निशामय। सर्वत्र चम्पक: शुद्धो भुवि भद्रप्रदस्तथा।|25 (Brahmavaivarta Purāna, Krṣnajanmakhaṇ, 103. 34-40)

32 तीर्थेषु पिण्डदानादिन्रोपकाणां ददन्ति ते। यत्नेनापि च राजेन्द्र अश्वत्थारोपणं कुरु।।

स ते पुत्रसहस्सस्य कृत्यमेक: करिष्यति। धनी चाश्वत्थवृक्षेण अशोक: शेकनाशनः।।

प्लक्षो यज्ञप्रदः प्रोक्तः क्षीरीचायुः प्रदः स्मृतः। जम्बुकी कन्यकादात्री भार्यादा दाडिमी तथा।।

अश्वत्थो रोगनाशाय पलाशो ब्रह्मदस्तथा। अज्ञेलो कुलवृद्धिस्तु खादिरेणापि रोगिता।।

निम्बप्रोहकाणां तु नित्यं तु येद्विवाकरः। श्रीवृक्षे शर्ज्यो देव: पाटलायां तु पार्वती।।

शिंशपायामप्सरसः कुन्दे गन्धर्वसत्तमाः। तिन्तिडीके दासवर्गा वज्जुले दस्यवस्तथा।।

पुण्यप्रद: श्रीपदश्च चन्दनः पनसस्तथा। सौभाग्यदश्चम्पकश्च करीर: पारदारिकः।।

अपत्यनाशकस्तालो बकुलः कुलवर्धनः। बहुभार्या नारिकेला द्राक्षा सर्वाड्गसुन्दरी।।

रतिप्रदा तथा कोली केतकी शत्रुनाशिनी।। (Padma Purāna-1. 28. 23-32)

33 प्रतिष्ठां पादपानां च वक्ष्येडहं भुक्तिमुक्तिदाम्। सर्वोषध्युदकैर्लिप्तान्पिष्टातकविभूषितान्।।

वृक्षान्माल्यैरलङ्कृत्य वासोभिरभिवेष्टयेत्। सूच्या सौवर्णया कार्यं सर्वेषां कर्णवेधनम्।। (Agni Purāna, 70. 1-2)
} 
invoked out of the heart of the trees by uttering abhiṣeka mantras. ${ }^{34}$

The consecration of trees and gardens imparts the highest merit to the consecrator and absolves him of all sins and demerits (Agni Purāna, 70. 8). Matsya Purāna has also discussed the process of consecration of trees and gardens (Matsya Purāna, 59. 1-19). The Purāna says that the wise, who observes the rites meant for consecration of trees and dedicated to plantation of trees, obtains all his desires and attains to endless felicity. One, who plants even one tree according to the prescribed rites, resides in heaven for over 30000 years of Indra. The planter of trees, according to the prescribed rites, liberates the same number of his past and future manes and attains the highest perfection, and is never reborn on earth.

Padma Purāna has also described the method of consecration of trees (Padma Purāna, 1.28.1-18). The Purāna says that he, who, plants the trees as per prescribed rites, attains great prosperity making rebirth difficult. Even that man, who listens to this, or makes others to listen to it, is honored by Gods in the world of Brāhman. The trees alone make a sonless person have a son (Padma Purāna, 1.28.23-24).

\subsection{Medicinal Importance of Plants}

The plants were held sacred in Purānic age. Emphasizing upon the significance of herbs it has been stated that one who has a store of herbs is like a mighty king. Herbs are the embodiment of nourishment and strength, which regenerate the human mind and body. Apart from many other Purānas, Agni and Garuḍa Purāna have discussed about the medicinal plant at length. Agni Purāna has described various categories of plants with their medicinal importance. These categories aredaśmūla (Agni Purāna, 279.22), pañcapallava (Agni Purāṇa, 224. 39), pañcabhaña (Agni Purāṇa, 299.25), pañcamūla (Agni Purāṇa, 285.2), phalatraya (Agni Purāna, 285.5), rajanīdvaya (Agni Purāna, 177.17; 265.6; 286.8, 23), baḍàga (Agni Purāna, 279.8), saptadhānya (Agni Purāna, 206.15), saptavrīhi (Agni Purāṇa, 212. 6), trikatu (Agni Purāna, 283.5, 19, 32; 302.7), triphala (Agni Purāna, 258. 27; 279.46, $50 ; 280.48 ; 281.25 ; 283.6,14,42,44)$ etc. Here there would be brief discussion regarding medicinal values of plants.

Purānas are replete with information on medicinal utilities of Aśvattha. According to Padma Purāna, it leads to destruction of diseases. ${ }^{35}$ For setting broken bones, Garuda Purāna says that one should take equal parts of aśvathha, triphala, vyoṣa and guggulu equal to their combined weight and mix. This compound has the virtue of setting broken bones. ${ }^{36}$

Agni Purāna: According to Agni Purāna, a decoction of the barks of aśvattha, udumbara, plaksa, madhuka and vama, boiled with a copious quality of water should be used in washing a wound, and for antiseptic purposes in general. ${ }^{37}$ The same Purāna says that a woman, eager to be the mother of a child, should take every day, a quantity of thickened milk saturated with powdered gulma, māsa, tila and vrīhi grass and the expressed juice of the root of vaisnavi, śri, bamboo, darbha and aśvattha. ${ }^{38}$ Agnipurāna also describes decoction of nyagrodha, triphala

\footnotetext{
34 हेमशलाकयाऽज्जनं च वेद्यां तु फलसप्तमकम्। अधिवासयेच्च प्रत्येकं घटान्बलिनिवेदनम्।।

इन्द्रादेरधिवासोऽथ होमः कार्यो वनस्पतेः। वृक्षमध्यादुत्सृजेद्गां ततोऽभिषेकमन्त्रतः।। (Agni Purāna, 70.3-4)

${ }^{35}$ अश्वत्थो रोगनाशाय (Padma Purāna, 1. 28. 26)

${ }^{36}$ अश्वत्थत्रिफलाप्योषा: सवराभिः समीकृतेः। तुल्यो गुग्गुलुना योज्यो भग्नसन्धिप्रसाधकः।। (Garuda Purāna, 171. 12)

${ }^{37}$ अश्वत्थोदुम्बरप्लक्षमधूकवटकल्कजैः। प्रभूतसलिलः क्वाथः सुखोष्णो व्रणशोधनः।। (Agni Purāna, 289. 30)

38 गुल्ममाषतिलव्रीहिचूर्णक्षीरसितान्वितम्। अश्वत्थवंशदर्भाणां मूलं वै वैष्णवी श्रियोः।।

मूलं दूर्वाश्वगन्धोत्थं पिबेक्ष्कीरै: सुतार्थिनी। (Agni Purāna, 302. 15-16)
} 
khadira, dārvī, atibalā, kuśa, nimba and mūlaka leaves for washing wound or an ulcer (Agni Purāna, 285.32-33). Agni Purāna further adds that a person suffering from cold and characteristic thirst should take decoction of nyagrodha, lodhra, dādima and madhūka mixed with honey and washing of rice (Agni Purāna, 285.13). Nyagrodha is one of the medicinal plants which is used in washing wounds. Agni Purāna says that a decoction of aśvattha, udumbara, plaksa, mahūka and nyagrodha boiled with a copious quantity of water should be used in washing a wound and antiseptic purposes (Agni Purāṇa, 289.29).

Garuḍamahāpurānạ: Garudamahāpurāna says that wise physician should employ a decoction of triphalā, khadira, dārvi and nyagrodha for washing all cuts, ulcers with an aching pain. ${ }^{39}$ To the problem of dysentery, the Garudmahapurāna says that sprouts of a Nyagrodha tree rubbed with the washings of rice should be administered for the purpose of curing any form of dysentery. ${ }^{40}$ The Purāna says that gargles of a decoction of vama, nimba and sami barks relieve the pain in the mouth due to the effects of poison. ${ }^{41}$ Medicinal oil cooked in combination with a decoction of vama, udumbara, plaksa, the two kinds of jambu, arjuna, pippalī, kadamba, palāśa, lodhra, tị̣duka, madhūka, āmra, sarjam badar, padmakeśar and śirịsa seeds brings on granulation even in old or long-standing sores, and facilitates their speedy healing (Garuda-mahāpurāna, 192.48).

The drugs àmalakī, abhayā, Krṣna, vahni, bilva, agnimantha, śyonāka, kaśmarī and pamala used in combination form the best febrifuge and may be safely given in all diseases (Agni Purāna, 285.3). Oil prepared with juice of ammalakī should be taken as snuff in all diseases of the head. ${ }^{42}$ Clarified butter mixed with the juice of amalaki fruit is the best unguent known for all sort of headaches and diseases of head. ${ }^{43}$ Oil prepared with the essence of amalakī, bhringa, yașthī, añjana fruits and an adhaka measure of thickened milk, would marvellously help the growth of hairs and eye lashes (Agni Purāna, 302.25).

Amalak $\bar{l}$ is sweet, relishing, constructive and aphrodisiac. ${ }^{44}$ Unsalted soup made with $\bar{a}$ malaki and Pomegranate improves digestion and destroys the $v \bar{a} y u$ and pitta disorders. ${ }^{45}$ Juice made with a malaki and mudga pulse is astringent and conquers the deranged kapha and pitta. ${ }^{46} \bar{A}$ malak $\bar{\imath}$ is anti-corpulent in its effect (Garuda Purāna, 170. 61). One who takes amalaki for a month is sure to get rid of all kind of skin diseases (Garuda Purāna, 174.24). In the Pittaja form of leucorrhoea the expressed juice of āmalaki seeds pasted with water and sweetened with honey and sugar should be administered. For the alleviation of $p \bar{a} n d u$ type of leucorrhoea a women should take the expressed juice of āmalakī with honey (Garuda Purāna, 171. 69-70). A decoction of àmalak̄̄, guḍuci and candana taken with honey proves curative in all forms of fever (Garuda Purāna, 175. 10). Ámalak̄̄ powder administered through the vehicle of clarified butter undoubtedly relieves cough (Garuda Purāna, 190. 29-30). A stick made of pippalī, tagara, haridrā, àmalakī, vacā and khadira pasted together with water and applied to

\footnotetext{
${ }^{39}$ त्रिफला खदिरो दार्वी न्यग्रोधो व्रणशोधनः। सद्य: क्षतं व्रणं वैद्य: सशूलं परिषेचयेत्।। (Garudamahäpurāna, 170. 72)

40 वटरोहाङ्कुरो रुद्र तण्डुलोदकघर्षितः। पीतः सतक्रोतोऽतीसारं क्षयं नयति शङ्करः।। (Garuḍamahāpuräna, 185. 24)

41 वटनिम्बशमीनाज्च वल्कलै: क्वथितं जलम्। तत्सेकान्मुखदन्तानां नश्ये्वै विषवेदना।। (Garudamahāpurāna, 191. 21)

$42 \ldots \ldots \ldots$......... तैलं धात्रीरसेऽपि वा। नस्यं सर्वामयेविष्टं मूर्ध्वजं तूद्भवेषु च।। (Agni Purāna, 279. 40)

${ }^{43}$ धात्रीफलान्यथाज्यं च शिरोलेपनसुत्तमम्। शिरोरोगविनाशाय ... ... ... ... ...। (Agni Purāṇa, 279. 43)

44 सुरमालकं वृष्यं मधुरं ह्यमम्लकृत्। (Garuḍa Purāna, 169. 22)

${ }^{45}$ दाडिमामलकैर्यूषो वह्निकृद्वातपित्तहा। (Garuda Purāna, 169. 59)

${ }^{46}$ मुद्ग्गामलकजो ग्राही श्लेष्मपित्तविनाशनः। (Garuda Purāna, 169. 60)
} 
eyes, proves curative in ocular affections. ${ }^{47} \mathrm{~A}$ compound consisting of pippali, ketaka, haridrā, $\bar{a}$ malak $\bar{l}$ and $v a c \bar{a}$ pounded together and applied to the eyes with the addition of milk proves beneficial in all forms of ocular affections. ${ }^{48}$ Daily use of a compound of nimba leaves and amalaki pounded together in the morning undoubtedly cures kuștha..$^{49}$ Abhayā, āmalakī, drākșā, pāthā, vibhitaka and sugar taken in equal parts and internally administered, act as a good febrifuge remedy. ${ }^{50}$ By taking, for a month powders of $\bar{a}$ malak $\bar{l}$ in combination with honey and oil, a person would verily become a lord of speech. ${ }^{51}$ Plasters composed of prapunnama seeds, àmalakī, sarjjarasa and snuhī pasted together with sauvira wine may be advantageously used in rubbing the patches. ${ }^{52}$ Powder of akșa taken through the medium of honey and expressed juice of amalaki, proves curative in all forms of cutaneous affections. This medicine is also possessed of good rejuvenating efficacy. ${ }^{53} \mathrm{~A}$ decoction of amalaki and khadira taken with valguja speedily cures even the most obstinate type of leucoderma. ${ }^{54}$ Drops of the expressed juice of àmalaki poured into the eyes, allay the local inflammation (Garuda Purāna, 175. 54). Powders of àmalakī, añjana and abhayā taken with water arrest the catsmenial flow (Garuda Purāna, 172.7).

Medical classics have come up with very useful information regarding medicinal values of the plants. Here focus would be mainly on those plants which have been discussed here while describing the medical uses of plants as discussed in Purānas.

Nighantus: According to Bhāvaprakāśa Nighanțu, aśvattha is astringent, difficult to be digested, cold, heavy, helpful in maintaining fair complexion, and cleansing genital organ. It also does away with disorders that start off bad effects of pitta and kapha. It is helpful in treating wounds and blood related diseases. ${ }^{55}$ Madanapāla Nighantu says that aśvattha is cool and dispels sorrow. It is helpful in treating diseases that develop due to kapha and pitta. It is helpful in healing wounds and treating blood disorders. Dhanvantari Nighantu is of the view that aśvattha has all the properties same as nyagrodha. Apart from those properties it does away with disorders that develop due to bad effects of raktapitta and kapha. ${ }^{56}$ Here it would not out of context to mention the medicinal properties of nyagrodha. Nyagrodha is cold, astringent, refrigerating, dry and does away with thirst related diseases, vomiting and bad effects of blood and pitta. ${ }^{57}$ As per Kaideva Nighantu, aśvattha is cold in potency, dry, astringent, cooked difficultly and heavy. It does away with diseases that may due develop due to bad effects of pitta and kapha. It is helpful in treating problems that might into fore due to blood disorder. It alleviates disorders of genital organs and bestows fair colour. ${ }^{58}$ So

\footnotetext{
47 कटुकं तगरं चैव हरिद्रामलकं वचा। खदिरा पिष्टवातश्च अग्जनान्नेत्ररोगनुत्।। (Garuda Purāna, 177. 14)

${ }^{48}$ पिप्पली केतकं रुद्रं हरिद्रामलकं वचा। सर्वाक्षिरोगा नश्येयुः सक्षीरादज्जनात्ततः।। (Garuda Purāna, 177. 69-70)

49 नित्यं निम्बदलानाज्च चूर्णमामलस्य च। प्रत्यूषे भक्षयेच्चैव तस्य कुष्ठ विनश्यति।। (Garuda Purāna, 190. 9)

${ }^{50}$ अभयामलकं द्राक्षा पाठा चैव विभीतकम्। शर्कराया समं चैव जग्धं ज्वरहरं भवेत्।। (Garuda Purāna, 193. 12)

51 रुद्रामलकचूर्ण वै मधुतैलान्वितम्। जग्धा मासं युवा स्याच्च नरो वागीश्वरो भवेत्।। (Garuda Purāna, 202. 22)

52 प्रपुन्नाटसुबीजानि धात्री सर्ज्जरस: स्नुही। सौवीरपिष्टं दद्रूणामेतदुद्वर्तनं परम्।। (Garuḍ Purāna, 171. 20)

${ }^{53}$ साक्षधात्रीरसः क्षौद्रो हन्यात्कुष्ठ रसायनम्।। (Garuḍa Purāna, 171. 25)

54 धात्रीखदिरयो: क्वाथं पीत्वा वागुजिसंयुतम्। शड्खेन्दुधवलं श्वित्रं हन्ति तूर्ण न संशयः।। (Garuda Purāna, 175. 26)

${ }^{55}$ पिप्पलो दुर्जरः शीतः पित्तश्लेष्मव्रणास्जित्। गुरुस्तुवरको रूक्षो वर्ण्यो योनिविशोधनः।। (Bhāvaprakāsa Nighanțu-Vamādivarga, 3)

${ }^{56}$ अश्वत्थोऽपि स्मृतस्तद्वद् रक्तपित्तकफावहः।। (Dhanvantari Nighantu-Āmrādivaraga, 73)

57 वटः शीतः कषायश्च स्तम्भनो रूक्षणात्मकः। तथा तृष्णाछर्दिमूर्छारक्तपित्तविनाशनः।। (Dhanvantari Nighantu-Ämrādivaraga/70)

${ }^{58}$ अश्वत्थो शीतलो रूक्षः कषायो दुर्जरो गुरुः।। व्रणपित्तकफास्रहो वर्ण्यो योनिविशोधनः। (Kaideva Nighantu-Oṣadhivarga/432-433)
} 
also described the medicinal properties of the aśvattha. According to this nighantu book, tvak (bark) and pravāla (leaves) are kașāya (astringent), it mitigates pitta. It is stambhana and hima. It cures vrana, prameha and atisāra. Fruits (phala) of kșìriv r̦kṣa (trees exudating latex/milky juice) are kașāya and madhura with sour (amla) taste (rasa). They are síta, rūkșa, guru, stambhana and lakhana. It mitigates kapha and pitta. It causes vibandha and ādhmāna. It aggravates vāta. (Sodhala Nighanțu, p. 285). According to Caraka Samhita, tender young leaves of aśvattha, nyagrodha, udumbara, plaksa, padma etc. are astringent, checking, cold and beneficial in pittaja diarrhoea. ${ }^{59}$ The fruits of aśvattha, udumbara, plaksa, nyagrodha are astringent-sweet, sour, aggravate $v \bar{a} t a$ and are heavy. ${ }^{60}$

Caraka Sam hitā: The Caraka Samhitā says that a physician desiring alleviation of raktapitta should use aśvattha in anointing, sprinkling, bath and preparation of ghee and oil (Caraka SamhitāCikitsāsthāna- 4.104). Decoction of aśvatha, pāthā, asana and vetasa added with honey has been prescribed for curing pittaja type of prameha (Obstinate urinary disorders including diabetes). ${ }^{61}$ Paste of bark of aśvattha, nyagrodha, udumbara, plaksa and vetasa mixed with ghee is an excellent cooling for inflammation. Decoction of aśvattha, nyagrodha, udumbara, kadamba, plakșa, vetasa, karavira, arka and kumaja are wound healers. Aśvattha, which falls under nyagrodhädi group of drugs according to Suśruta Saṃhitā is beneficial for wound healing, is astringent, helps in healing of fractures and dislocations, cure haemorrhagic diseases, burning sensation, adiposity and vaginal disorders (Suśruta Saṃhitā-Sūtrasthāna- 38.4849). Persons, drinking milk cooked with fruits, root, bark and sprouts of an aśvattha tree and mixed with sugar and honey, become as vigorous (sexually) as a sparrow (kulinga). ${ }^{62}$ While discussing the management of ear diseases, Suśruta Saṃitā says, a bowl-shaped cup, prepared from the oil soaked leaves of aśvattha, should be completely filled with the burning charcoal covered by a thick layer of more leaves and should be placed over the aching ear. The oil being heated with the burning charcoal, will drop from this cup into the ear and on getting inot channels of the ear, will immediately take away the pain. ${ }^{63}$ According to Sidhabhesaja-manimālā, decoction of the root bark of aśvattha added with Jaggery, by intake, alleviates severe colic (Sidhabhesajamanimālā-4.506). According to Vrndamädhava, dusting with powder of the dried bark of aśvattha promotes healing in burns (Vrndamädhava-45.21). In children, if there is inflammation in the mouth, the paste of bark and leaves of aśvattha should be applied (Cakradatta64.49). It is also sprinkled over unhealthy ulcers to improve their condition and promote granulation (Materia Medica of Hindus- p 236).

Bhāvaprakāsáa: Âmalakī is equal to harîtakī in properties and still especially cures bleeding diseases, diabetes, best aphrodisiac and rejuvenator, mitigates vāta by its sour taste, pitta by its sweet taste and cold potency, kapha by dryness and astringent taste, thus fruit of amalaki mitigates all the three doșās. ${ }^{64}$ As a malaki is similar to haritaki in properties, it is necessary to know its properties. According to Bhāvaprakāśa

\footnotetext{
59 न्यग्रोधोदुम्बराश्वत्थप्लक्षपद्मादिपल्लवाः । कषायाः स्तम्भनाः शीता हीताः पित्तातिसारिणाम् ।। (Caraka Samhitā-Sūtrasthāna, 27.105-106)

${ }^{60}$ अश्वत्थोदुम्बरप्लक्षन्यग्रोधानां फलानि च। कषायमधुराम्लानि वातलानि गुरूणि च।। (Caraka Samhitā-Sūtrasthāna, 27.165)

61 अश्वत्थपाठासनवेतसानाम् । (Caraka Saṃhitā-Cikitsāsthāna, 6.32)

62 अश्वत्थफलमूलत्वक्शुड्गासिद्धं पयो नरः। पीत्वा सशर्कराक्षौद्रं कुलिड्ग इव हृष्यति (Suśruta Saṃhitā-Sūtrasthāna, 26.27-28)

${ }^{63}$ अश्वत्थपत्रखल्लं वा विधाय बहुपत्रकम्। तदड्गारै: सुसम्पूर्ण निदध्याच्छ्र्रणोपरि।।

यत्तैलं च्यवते तस्मात् खल्लादड्गारतापितात्। तत् प्राप्तं श्रवणस्रोतः सद्यो गृहृणाति वेदनाम् (Suśruta Samhitā-Uttartantram, 21.9-10)

${ }^{64}$ हरीतकीसमं धात्रीफलं किन्तु विशेषतः। रक्तपित्तप्रमेहहनं परं वृष्यं रसायनम्।।

हन्ति वातं तदम्लत्वात्पित्तं माधुर्यशैत्यतः। कफं रुक्षकषायत्वात्फलं धार्त्यास्रिदोषजित्।। (Bhāvaprakāśa-Harītakyādi varga, 39-40)
} 
it possesses five tastes, not having salt taste, very astringent, rūkṣa (dry), uṣna (hot in potency), stimulates digestive fire, good for intelligence, sweet at the end of digestion, rejuvenates the body, good for eyes (vision), light (easily digestible), stoutens the body, initiates downward movement (of faeces, flatus, urine etc.), cures dyspnoea, cough, diabetes, haemorrhoids, leprosy (and other skin diseases), dropsy, enlargement of the abdomen, worms, hoarseness, disease of the duodenum, constipation, intermittent, abdominal tumour, flatulence, thirst, vomiting hiccup, itching, heart diseases, jaundice colic, tympanitis, diseases of the spleen and liver, renal calculus, dysuria and retention of urine (Bhāvaprakāśa-Harītakyādi varga/19-22).

Nighaṇtu: According to Soḍhala Nighaṇtu, $\bar{a}$ malaki is cold in potency. It mitigates pitta due to cold and sweet taste. Pungent effect is responsible for mitigation of kapha; and sour taste mitigates vāta. Thus it alleviates tridosa. It is aphrodisiac, beneficial to throat and eye and cardiac. It cures burning sensation and fever. Its marrow alleviates gynaecological disorders, vomiting, vāta, pitta and thirst. It has astringent and sweet taste and effect respectively. It enhances sukra. It alleviates cough, diarrhoea and other ailments and colic type of pain in the abdomen (Sodhala Nighantu, 2005, p. 221). Several other Nighanțu books including Dhanvantari Nighaṇtu (Gud̄̄ucyādivarga, 212-213), Madanapāla Nighaṇtu (Abhayādivarga, 27), Rāj Nighaṇtu (Āmrādivarga, 158), Priya Nighaṇmu, Kaiyadeva Nighanțu (Oșadhivarga, 236-240) etc. have also come up with medicinal properties of amalakī. Juice of grapes and amalaki fruit acts as purgative as well as anti-pyretic. Similar is the juice of amalaki fried with ghee. ${ }^{65}$ The patients having no diaphoresis and sleep and having excessive thirst should take the liquid gruel fried with ghee and cooked with sunthi and amalaki and added with sugar. These act as anti-pyretic. ${ }^{66}$ Khanda, which is a dietary preparation made of kāsmarya and $\bar{a}$ malaki and taken with supernatant fatty layer of curd is helpful in controlling excessive bleeding, if administered properly (Caraka Samhitā, Ci, 14.202). Dhātryāvaleh, a special preparation made up of $\bar{a}$ malak̄ alleviates jaundice, disorders of pitta, pāṇụ, kāsa and hatimaka (Caraka SaṃhitāCi, 16. 100-102). Dhātryārișta, another preparation should be taken in morning in proper dose keeping on wholesome and measured diet on digestion. This arișta alleviates jaundice, anaemia, heart disease, vātarakta, malarial fever, cough hiccup and anorexia. ${ }^{67}$ Amalaki fruits mixed with plenty of honey and sugar should be used as purgative. It is efficacious in treating raktapitta ${ }^{68}$ The amalakyādi group of drugs brings down all types of fever, is beneficial for the eyes, is an appetizer and aphrodisiac and cures kapha and anorexia. ${ }^{69} \bar{A}$ malak $\bar{l}$ is cold, dry and curative for pitta, medas and kapha. ${ }^{70} \bar{A}$ malaki fruit is sour, sweet, bitter, astringent and acrid in taste and is a laxative, is beneficial for the eyes, pacifies all the dosas and is spermatogenic. Due to its sourness taste it eliminates $v \bar{a} t a$; due to its sweetness and coolness it eliminates pitta; due to its dryness and astringent property it pacifies kapha and hence it

\footnotetext{
${ }^{65}$ मृद्वीकामलकानां वा रसं प्रस्कन्दनं पिबेत्। रसमालककानां वा घृतभृष्टं ज्वरापहम्।। (Caraka Saṃitā-Ci, 3. 230)

${ }^{66}$ अस्वेदनिद्रस्तृष्णार्तः पिबेत् पेयां सशर्कराम्। नागरामलकै: सिद्धां घृतभृष्टां ज्वरापहाम्।। (Caraka Samhitā-Ci, 3. 187-188)

67 प्रपिबेन्मात्रया प्रातजीर्णे हितमिताशनः। कामलापाण्डुहृद्रोगवातासृग्विषमज्वरान् । | 
is the best of all the fruits. ${ }^{71}$ The leaves and fruits of amalaki cooked in the manner of rasakriya should be employed as collyruim. ${ }^{72}$

\section{Concluding Remarks}

The Purānas state that trees provide food, shade, fuel and wood. So they should be produced, protected and donated to the society. Multiple utilities of plants have been realised from times immemorial and these make the plants as one of the oldest forms of adoration. Hence, plants are considered holy. The concept of tree worship occupies an important place in the religious moorings of Indian people. They are often associated with many myth and folklore. The plants are associated and identified with Gods, planets, months etc. Tree worship is possibly earliest and the most prevalent form of the religion. The sense of worship combines utility and spirituality. Without trees there shall be no life on the earth. Man has been in communion with nature since time immemorial. Along with the progress of his intellect the man-plant relationship also progressed. Indeed tree is the highest and noblest production of the plant kingdom just as man in the highest in animal kingdom. Trees always provide freshness, variety and often grandeur to the scene, whether they stand solitary or arranged in masses or avenues.

According to Purānāas, trees have played a vital role in the field of human welfare and they are doing it even now. They shall be playing this important role so long the human life exists on the face of the earth. There is perhaps no object in the nature that adds so much to the beauty of a landscape as a tree. Well it has been said that man cannot live without trees. They mitigate the severity of the climate, protect the soil and conserve the water. Plants have been integral part of Indian life and culture. Owing to its importance in day-to-day human life and environment balance, ancient seers of India did all that was possible to conserve and preserve plants. They developed the concept of tree worship apart from discussing the merits of plantation. How felling or cutting of trees was considered as sin and hazardous have been discussed in ancient Sanskrit Literature. As plants are required for healthy environment, thoughts for plant conservation were given prominence in ancient India. If those thoughts are practised in modern era too, problems of environment pollution could easily be met.

It is clear that the Purānas have described importance of plants at length. Emphasis of Purānas in unearthing religious and cultural facts relating to plants on one hand and interesting information on economical, ecological, environmental and medicinal values of plants justifies also human health, safety and prosperity of the society.

\section{ACKnowledgement}

The Author is highly thankful to Prof. (Dr.) N.R. Dubey (Former Head, Dept. of Sanskrit, Doranda College, Ranchi) for his valuable guidance and directions.

\section{Bibliography}

Agni Mahāpurāṇam (ed.) Puṣpendra Kumar. Eastern Book Linkers, Delhi, 2006

Atharvaveda (tr.), Shastri, Acharya VN. Sarvadeshik Arya Pratinidhi Sabha, New Delhi, 2003

Banerji, Sures Chandra. Flora and Fauna in Sanskrit Literature, Naya Prokash, Calcutta, 1980

Bennet, S S R, Gupta P C and Rao Vijendra. Venerated Plants, Indian Council of Forestry Research and Education, Dehradun, 1992

\footnotetext{
${ }^{71}$ अम्लं समधुरं तिक्तं कषायं सरम्। चक्षुष्यं सर्वदोषहनं वृष्यमामलकीफलम्।।

हन्ति वातं तदम्लत्वात् पित्तं माधुर्यशेत्यतः। कफं रुक्षकषायत्वात् फलेभ्योऽभ्यधिकं च तत्।। (Suśruta Saṃhitā-Su, 46. 143-144)

72 पत्रं फलं चामलकस्य पक्त्वा क्रिया विदध्यादथवाऽज्जनार्थे। (Suśruta Samhitā-Utta, 12.49)
} 
Bhāvaprakāśa Nighaṇtu (ed.). Pandey, G.S. Chaukhamba Bharati Academy, Varanasi, 1999

Bhavișyamahāpurāṇa, Pandit Baburam, Upadhyay. Hindi Sahitya Sammelan, Prayag, 1995

Brahmāṇda-Mahāpurāṇa (ed.), Sharma, K V. Krishnadas Academy, Varanasi,1983

Brahmavaivartapurāṇam, (tr.) Jha, Taranisha. Hindi Sahitya Sammelana Prayaga, Allahabad, 2001

Caraka-Saṃhitā (tr.), Sharma, Priyavrat. Chaukhamba Orientalia, Varanasi, 2008

Dagar, J C. Trees and Shrubs in Religion and Mythology, Tree World, Vol. 3, No.6, 1995.

Dhanvantarinighantu (ed.). Tripathi Hariharprasad, Chowkhamba Krishnadas Academy, Varanasi, 2008

Dutta, U C. Materia Medica of Hindus, Krishnadas Academy, Varanasi, 1980

Dwivedi, Dhananjay Vasudeo. Aśvattha (Ficus religiosa Linn.) in Indian Tradition, Shri Krishna Sahitya Sadan, Delhi, 2015

Dwivedi, Dhananjay Vasudeo. Bilva in Indian Tradition, IJHS, 47.1 (2012):37-62

Dwivedi, Dhananjay Vasudeo. Nyagrodha Vṛșa in Indian Tradition, Shri Krishna Sahitya Sadan, Delhi, 2013

Dwivedi, Dhananjay Vasudeo. Plant Diseases and their treatment in Sanskrit Literature, IJHS, 49.3 (2014):239-250

Dwivedi, Dhananjay Vasudeo. Sanskrit Sāhitya mem Paryāvarana Cetana, Shri Krishna Sahitya Sadan, Delhi, 2013

Garrett, John. A Classical Dictionary of India, Low Price Publications, Delhi, 1996

Garuda-mahāpurāṇam (ed.), Kumar, Pushpendra. Eastern Book Linkers, Delhi, 2006

Garuḍamahāpurāṇa, (ed.), Pandey, Pt. Ramateja. Chowkhamba Vidyabhawan, Varanasi, 2005

Gupta, Shakti M. Plant Myths and Tradition, Munshiram Manoharlal Publishers Pvt. Ltd., 2001

Kaiyadeva-Nighaṇtuh (ed. \& tr.), Sharma, Priyavrat and Dr. Guru Prasad Sharma. Chaukhambha Orientalia, Varanasi, 2006

Kashyapiyakrishisukti (tr.), Ayachit S.M. Asian Agri-History Foundation, Secunderabad, 2002
Krishi Parashara (tr.), Sadhale Nalini. Asian Agri-Histroy Foundation, Secunderabad, 1999

Krishna, Nanditha \& Amrithalingam, M. Sacred Plants of India, Penguin Books, Gurgaon, 2014

Krishna, Rani Rama, Science in Krṣna Yajurveda, Sri Jayalakshmi Publications, Hyderabad, 1994

Kumar, Acharya Prasanna. An Encyclopaedia of Hindu Architecture, Low Price Publications, Delhi, 2001

Kūrma Mahāpurāṇa (tr.), Shanti Lal Nagar. Parimal Publications, Delhi, 2008

Linga Mahāpurāna (ed.), Mishra, Shastri Pt. Dwarka Prasad, Chowkhamba Sanskrit Series Office, Varanasi, 2008

Madanpāla Nighaṇtu (tr.), Sankhyadhar, J.L.N. Sastry. Chaukhambha Orientalia, Varanasi, 2010

Manusmrti (ed.), Deshpande, Maitreyee. New Bharatiya Book Corporation, Delhi, 2010

Mānasollāsa (ed.), Shrigondekar, Gajanan K. Central Library, Baroda, 1925

Mārkaṇdeya Mahāpurāṇam (ed.), Singh, Nagsharan. Rashtriya Sanskrit Sansthan, 2002

Matsyamahāpurāṇa, (ed.), Kumar, Pushpendra. Eastern Book Linkers, Delhi, 2009

Matsyamahāpurāṇa, Vedavyāsa. Gita Press, Gorakhpur, Samvat 2061.

Matsyamahāpurāṇam (tr.), Śrīśchandra, Rai Bahadura. Eastern Book Linkers, Delhi, 2009

Misra, Shiva Sheikhar. Fine Arts \& Technical Sciences in Ancient India, Krishnadas Academy, Varanasi, 1982

Müller F. Max (ed.), The Sacred Books of the East, Low Price Publications, Delhi, 1996

Nārada-Purāna, (tr.), Tagare, G V. Motilal Banarasidass Publishers, Delhi, 1995

Oldemberg, Hermann (tr.), The Sacred Books of the East, Low Price Publications, Delhi, 2009

Padma-Purāna (tr.) Deshpande, N A. Motilal Banarasidass Publishers, Delhi, 1989

Padmapurāṇam, Vedavyāsa. Chowkhamba Sanskrit Series Office, Varanasi, 2007

Panchamukhi, A R. Socio Economic Ideas in Ancient Indian Literature, Rashtriya Sanskrit Sansthan, New Delhi, 1998 
Prakash, Om. Economy and Food in Ancient India, Bharatiya Vidya Prakashan, Delhi, 1987

Rāj Nighạ̣tu (tr.), Sankhyadhar, Dr. Satish Chandra. Chaukhambha Orientalia, Varanasi, 2012

Sharma, P.V. Classical Uses of Medicinal Plants, Chaukhambha Visvabharati, Varanasi, 2004

Skanda Mahāpurāna (ed.), Krishnadas, Khemraj. Rashtriya Sanskrit Sansthan, New Delhi, 2006

Skanda-Purāna (tr.), Tagare, G V. Motilal Banarasidass Publishers, Delhi, 1993

Śiva Puraṇa (tr.), Nagar, Shanti Lal. Parimal Publications, Delhi, 2007

Soḍhala Nighanțụ (ed.), Dwivedi, R R. Chowkhamba Krishnadas Academy, Varanasi, 2009

Suśrutasaṃitā of Suśruta (ed.), Singhal G. D. Chaukhamba Sanskrit Pratishthan, Delhi, 2007

Śrīmadbhāgvata Mahāpurānam. (ed.), Kumar, Pushpendra. Eastern Book Linkers, Delhi, 2009

Śrimad Bhāgavata Mahāpurāṇa, (tr) Goswami, C L. Gita Press, Gorakhpur, 1982

Swami Harshananda. A Concise Encyclopaedia of Hinduism, Ramakrishna Math, Bangalore, 2008

Trikha, Nirmal. Scientific Knowledge in Sanskrit Literature, Eastern Book Linkers, Delhi, 2009

Upavana-Vinoda (tr.) Prasanna, Majumdar Girija. The Indian Research Institute, Calcutta, 1935
Vāmana Purāṇa, Vedavyāsa. Gita Press, Gorakhpur, Samvat 2059

Vāmana Purāṇa, (ed.) Joshi, K L and Bimali, O N. Parimal Publications, Delhi, 2005

Varāhmihira's Bṛhat Saṃhitā, (Part II) Bhat, M. Ramakrishna. Motilal Banarasidass Publishers, Delhi, 2003

Varāhpurāna (ed.) Gupta, Shree Anandswaroop. Sarvabharatiya Kashirajnyas, Varanasi, 1983

Vāyu Purāna, (tr.), Sharma, Sudarshan Kumar. Parimal Publications, Delhi, 2008

Vāyu Purāna, (tr.), Tripathi, Ram Pratap. Hindi Sahitya Sammelan, Allahabad, 2005

Vishveshvaranand Indological Journal, Hoshiarpur

Vishvavallabha (tr.), Sadhale Nalini. Asian Agri-Histroy Foundation, Secunderabad, 2004

Viṣnumahapurāṇa (ed.), Kumar, Pushpendra. Eastern Book Linkers, Delhi, 2005

Viṣnu Purāṇa, Vedavyāsa. Gita Press, Gorakhpur, Samvat 2059

Vṛkṣāyurveda (ed.), Jugnu, Shrikrishna. Chowkhamba Sanskrit Series Office, Varanasi, 2004

Vṛsṣāyurveda of Parāśara (ed.), Sircar, N N and Sarkar Roma (A Treatise on Plant Science). Sri Satguru Publications, Delhi, 1996 